\section{Estudo \\ CoDebate}

em Testão

Plamejamento
Revista Estudo \& Debate, Lajeado, v. 23, n. 2, 2016. ISSN 1983-036X

DOI: http://dx.doi.org/10.22410/issn.1983-036X.v23i2a2016.1081

\title{
LOCAL CORRELATIONS BETWEEN PRICING DEVIATION AND MARKET PROXY OF BRAZILIAN ETFs
}

\author{
Bruno Milani ${ }^{1}$, Paulo Sergio Ceretta ${ }^{2}$
}

\begin{abstract}
The Exchange Traded Funds (ETFs) have become a wide-spread investment vehicle with unique characteristics that have not been sufficiently studied yet, especially when it comes to emerging markets ETFs. Moreover, consolidated asset pricing models are not enough to analyze the dynamics of a kind of fund that adds a different dimension in relation to conventional investment funds: the variation of share prices. The difference between share prices and their net asset values (NAVs) is called pricing deviation. The goal of this paper is to verify if Brazilian ETFs pricing deviation depends on market returns and if this relationship presents differences according to market situations, before and after the European debt crisis. With the local correlation approach, our results pointed to the fact that the correlation between pricing deviation and the market return is much higher in extreme points and it becomes even higher after the beginning of the Eurozone debt crisis.
\end{abstract}

Keywords: Brazilian ETFs; Pricing Deviation; Local Correlation.

\section{CORRELAÇÓES LOCAIS ENTRE O DESVIO DE PRECIFICAÇÃO E A PROXY DE MERCADO DOS ETFs BRASILEIROS}

Resumo: Os Exchange Traded Funds (ETFs) se tornaram um veículo de investimentos bem disseminado, com características únicas que ainda não foram suficientemente estudadas, especialmente em relação aos ETFs de mercados emergentes. Ainda, modelos de precificação consolidados não são suficientes para analisar a dinâmica de um tipo de fundo que adiciona uma dimensão diferente em relação a fundos de investimento convencionais: a variação do preço das cotas. A diferença entre o preço das cotas e seus valores de patrimônio líquido é chamada de desvio de precificação. O objetivo deste artigo é verificar se o desvio de precificação dos ETFs brasileiros depende dos retornos do Mercado e se esta relação apresenta diferenças de acordo com situaçóes do Mercado, antes e depois da crise da dívida europeia. Com a abordagem da correlaçáo local, os resultados apontaram para o fato de que a correlação entre o desvio de precificação e o retorno do Mercado é muito maior em pontos extremos e se torna ainda maior depois do início da crise da dívida europeia.

Palavras-chave: ETFs brasileiros. Desvio de Precificação. Correlaçáo Local.

1 Professor do eixo de Gestão e Negócios do Instituto Federal de Educação, Ciência e Tecnologia Farroupilha; Doutorando em Administração pelo PPGA-UFSM (Linha de Pesquisa: Economia, Controle e Finanças).

2 Doutor em Engenharia da Produção pela Universidade Federal de Santa Catarina (UFSC). Professor do Departamento de Administraçáo da Universidade Federal de Santa Maria (UFSM). 


\section{INTRODUCTION}

Exchanged Traded Funds (ETFs) have become a wide-spread investment vehicle with unique characteristics that have not been sufficiently studied, especially when it comes to emerging markets ETFs. Also, consolidated asset pricing models are not enough to analyze the dynamics of a kind of fund that adds a different dimension in relation to conventional investment funds: the variation of share prices.

The traditional CAPM model, developed by Sharpe (1964), Lintner (1965) and Mossin (1966) was based on the relationship between risk and return, outlined by Markowitz (1952). Jensen (1967) applied the CAPM model to the mutual fund performance evaluation, calculating how much a mutual fund variation depends on the systematic (market) variation (beta), how much is due to manager ability (alpha) and how much is due to idiosyncratic risk (residual). But ETFs present considerable differences from traditional mutual funds, like traded shares. So, investors face the fact that its share price is different from its net asset value (NAV), an unadvised feature of this investment kind.

There are not many studies regarding the relationship between ETF share price and NAV and their relationship with the market return. A concise review of the recent developments is provided by Charupat and Miu (2012), that have identified three main literature strands: (a) the ETFs pricing efficiency (how close ETFs prices are from their NAVs); (b) the ETFs performance (how successfully they are achieving their objectives, measuring the difference between NAV returns and underlying index returns); (c) the effects of ETF trading on their underlying securities. Exchange Traded Funds of emerging markets have received even less academic attention, although they have become increasingly important for investors due to their fast growing economies.

Brazilian ETFs were created in January 2002 by the instruction no 359 of Comissão de Valores Mobiliários (CVM), a governmental institution that regulates Brazilian financial market. As international ETFs, they should track a reference index, commonly the Ibovespa Index, which represents Brazilian market. However, differently from the U.S. ETFs, they don't pay dividends to shareholders as they reinvest the stock dividends in their portfolios.

Instruction no 359 of CVM determines that at least 95\% of an ETF equity should be invested in assets traded in a stock exchange market or in other assets authorized by the CVM, in the same proportion that they integrate the fund reference index, or invested in index futures. This way the ETF is assured to reflect its reference index variation. The remaining $5 \%$ of the fund equity can be invested in government bonds, fixed income bank investments, fixed income mutual funds, commitment transactions and derivatives (exclusively for risk management of the fund portfolio).

In Brazilian market, the ETFs are one of the few kinds of investment funds that can trade shares at a stock exchange market, unlike other markets like the U.S. where this is available to other kinds fund types, such as the closed-end funds (CEFs). Funds with traded shares puzzle the investors in the way that their total share prices may represent a different value of their underlying fundamentals, i.e., their net asset values (NAVs). The difference between share prices and their NAVs is called Pricing Deviation and some studies as Berk and Stanton (2007) point out its persistence may explain share prices. However, pricing 
deviation is still not very well explained by the current literature and this type of funds challenges conventional models of asset pricing. The goal with this paper is to verify if Brazilian ETFs pricing deviation depends on market returns and if this relationship present differences depending on market situations, before and during the eurozone debt crisis. Section 2 presents a brief review of the late studies on this subject. Section 3 presents the data analyzed and the local correlation method; Section 4 discusses the results and, finally, Section 5 brings the concluding remarks.

\section{THEORETICAL ISSUES}

Charupat and Miu (2012) analyzed the recent developments in ETF literature, concluding that three main trends arise: i) pricing efficiency, ii) tracking ability/ performance and iii) effects on underlying securities. Regarding pricing efficiency, most studies examine pricing deviations, i.e. whether ETFs trade at a premium or discount to their NAVs. In the same sense, other studies look at the speed the premium/disco unts disappears, what indicates how well arbitrage works. They point that, in general, premiums/discounts are small and do not persist, especially for ETFs that track major U.S. equity indices.

No pricing deviations are found by Ackert and Tian (2000) and Elton et al. (2002). Curcio et al. (2004), Engle and Sarkar (2006) have found small average deviations. Jares and Lavin (2004) have examined pricing deviations from Japan and Hong Kong ETFs with daily data from March 1996 through December 2001. They defined their measure of discount as a percentage discount from NAV and computed it as the difference between the NAV and the ETF market closing price divided by NAV, as shown in Equation (1).

$$
P D_{t}=\frac{\left(N A V_{t}-E T F_{t}\right)}{N A V_{t}} .
$$

Where $P D_{t}$ is the pricing deviation percentage in period $t, N A V_{t}$ is the net asset value of the fund in period $t$ and $E T F_{t}$ is the closing price of the fund in period $t$. Therefore, when the market closing price is less than the net asset value, the pricing deviation is positive and the ETF trades at a discount. When the market closing price exceeds the NAV, the ETF is said to trade at premium. The same method is used by Charupat and Miu (2013) to measure the pricing deviations of leveraged ETFs (LETFs). They used the 10 largest bear and the 10 largest bull leveraged ETFs in the U.S. market, since the fund inception until the end of 2011. They conclude that, in general, ETFs and LETFs have small pricing deviations, which can disappear due to transactions costs and bid-ask spread. However, LETFs present large pricing deviations sometimes. Moreover, the higher the leverage ratios, the more prone they are to large deviations; funds on the same side of the market have positively correlated pricing deviations; price deviations of bull (bear) funds are positively (negatively) correlated with the returns on their own underlying index.

Jares and Lavin (2004) also estimated the ETF returns as a function of its discounts (contemporaneous and lagged) and analyzed passive and active strategies. They found a strong negative relation between contemporaneous discounts and returns for both countries. While this may suggest that there is a potential profitable trading opportunity 
in these ETFs it also suggests that the market perhaps overreacts to these opportunities on the subsequent day.

Chung and Hrazdil (2012), based on Chordia et al. (2005) verified the speed of convergence to market efficiency in the ETF market for 273 ETFs that were active with trades reported for every trading day on Arca throughout the first six months of 2008. They based their analysis on short-horizon return predictability from past order flows and compared the corresponding informational efficiency of prices to that of ordinary shares traded on the NYSE and the Arca platform. Despite the significant differences in trading costs, volatility and informational effects, they found that the adjustments on new information for ETFs occur in approximately 30 minutes. This time is driven by volume and by probability of informed trading.

Marshall et al. (2013) found evidences of arbitrage opportunities with intraday data of the two most liquid S\&P500 ETFs: SPY and IVV. Although they are not identical, the correlation and error correction term suggest that investors view them as close substitutes. When mispricing happens, liquidity declines and order imbalance increases. Also, return volatility and liquidity volatility are higher when arbitrage opportunities occur.

Recent literature developments suggests, according to Charupat and Miu (2012), that Price deviations are larger and more volatile for ETFs that track international indexes, which are normally referred as international ETFs or country ETFs. This may happen due to the fact that the NAVs used in calculations are based on prices from earlier closing times than the U.S. market close. Leveraged ETFs consist on a new but very popular type of ETFs, which focus to generate daily returns that are a multiple of the daily returns of its underlying index. In order to do this, they trade derivatives such as future contracts, forward contracts and total-return swaps.

Defusco et al. (2009) analyze the pricing deviation of the three most liquid U.S. ETFs from the price of its underlying index with a different measure. They based their analysis on the fact that there is a persistent pricing deviation associated with the price forming processes (Elton et al. 2002). Their pricing deviation measure may be defined as Equation (2).

$$
P_{t}^{M}=\alpha+\beta_{1}+P_{t}^{i}+P D_{t}
$$

Where $P_{t}^{M}$ is the price of the market index in period $t, P_{t}^{i}$ is the price of the ETF $i$ in period $t$ and $P D_{t}$ is the price deviation in period $t$. Defusco et al. (2009) shows that the creation and redemption of ETF units leave a predictable and non-zero pricing deviation.

The tracking error, according to Charupat and Miu (2012), can be defined as the deviation of the return on the NAV of an ETF from the corresponding return on its underlying benchmark index. Unlike price deviations, which are typically expected to be within the arbitrage bounds given the creation/redemption process of ETFs, any deviations of NAV return from those of their underlying benchmarks could accumulate over time and thus significantly affect the ETF long-term performance. Some reasons that could lead to 
tracking errors are: management fees, transaction costs, dividends, replication strategy and the compounding effect of leveraged and inverse ETFs.

There are several methods for measuring the tracking errors, as defined by Charupat and Miu (2012). These measures are:

1. the average absolute difference between the return on the fund and that of the underlying benchmark index;

2. the root mean square deviation of the return on the fund from that of the benchmark;

3. the standard deviation of the difference between the return on the fund and that of the benchmark;

4. The standard error of the regression of the return on the funds on that benchmark.

The fourth measure can be exemplified by equation (3).

$$
R_{t}^{N A V}=\alpha+\beta R_{t}^{M}+\varepsilon_{t}
$$

Where $R_{t}^{N A V}$ is the NAV variation of ETF $i$ on period $t, R_{t}^{M}$ is the market return on period $t, \varepsilon_{t}$ is the error term; $\alpha$ and $\beta$ are parameters. Similarly to Jensen (1967) model, a positive (negative) estimated value of the intercept will suggest the ETF outperforms (underperforms) the underlying index.

The performance comparison between ETFs and closed-end funds was analyzed by Harper et al. (2006), that calculated the tracking error as the difference between the ETF return and the market return. Sharpe (1966) was used in a sample period that comprises April 1996 to December 2001 (monthly data), verifying that there is a small tracking error and that the ETFs Sharpe Index was higher than the closed-end fund Sharpe index.

Ackert and Tian (2008) analyzed the performance and pricing (especially regarding liquidity) of U.S. ETFs and Country ETFs traded on the United States from 2002 to 2005. They regressed the premium (ETF minus NAV, in this case) against Amihud liquidity measure, besides momentum, traded volume and market capitalization variables. They reported that for country funds, during the beginning of their activity, there were persistent and large premiums. Even in the cases where the premium was small its variation could be quite large. These premiums are related to all independent variables analyzed.

Charupat and Miu (2012) verified that despite their generally low expense ratios and their tax-friendly design, ETFs do not necessarily outperform their index mutual fund competitors even on an after-tax basis. There are empirical evidence suggesting that ETFs and mutual funds are substitutes for each other. Small tracking errors and underperformance situations are found by Elton et al. (2002).

The discussion on management style is also a relevant issue on ETFs studies. Rompotis (2013) applied standard mutual fund methodology to evaluate actively and passively managed ETFs using US data of 18 ETFs. Active ETFs present lower returns and are more risky, but none styles were able to beat the market. 


\section{METHOD}

Our analysis is based on three variables: ETFs share return, ETFs NAV variation and Ibovespa (market proxy) return, with daily data. We used two subsamples: the first from March $1^{\text {st }}, 2009$ to July 29 ${ }^{\text {th }}, 2011$ and the second from July 30 ${ }^{\text {th }}, 2011$ to March 29 2012. The first period is characterized as the post subprime crisis and the second, as the euro zone debt crisis. We chose the 10 largest Brazilian ETFs, between those that were available for the entire sample period.

To generate the pricing deviation series, we estimated an OLS regression using ETF share return as dependent variable and NAV variation as independent variable, differently of Jares and Lavin (2004) and Charupat and Miu (2013). This way, we priced the ETF return in function of NAV variation and generated an error series which represent the nonexplained return, i.e., the portion of the return that does not depend on NAV variation, as shown in Equation (4).

$$
R_{E T F, t}=\alpha+\beta_{1} R_{N A V, t}+\varepsilon_{t}
$$

Where $R_{E T F, t}$ is the return of the ETF share in period $t ; R_{N A V, t}$ is the NAV variation in period $t ; \alpha$ is the linear coefficient; $\beta_{1}$ is the sensibility of $R_{E T F, t}$ to $R_{N A V, t}$ and $\varepsilon_{t}$ is the error on period $t$. The error term is our pricing deviation $(P D)$. Considering that the pricing deviation may depend on market return, we estimate the Gaussian local correlation between $P D$ and the market proxy (Ibovespa return).

Following Inci et al. (2010), the local correlation between the Pricing Deviation $(P D)$ and the Ibovespa return $\left(R_{M}\right)$ is given by

$$
\rho(P D)=\beta(P D) \frac{\sigma_{P D}}{\sigma_{R_{M}}}=\frac{\sigma_{P D} \beta(P D)}{\left[\sigma_{P D}^{2} \beta^{2}(P D)+\sigma^{2}(P D)\right]^{1 / 2}},
$$

Where $\sigma_{P D}$ is the standard deviation of $P D$ and $\sigma_{R_{M}}$ is the standard deviation of $R_{M}$ As in Mathur (1998) and Bradley and Taqqu (2005a, 2005b), $\beta(P D)$ is estimated by using local polynomial regression, and $\sigma^{2}(P D)$ is estimated by applying local linear regression. Specifically, the polynomial regression function $m(x)$ is taken to be $q+1$ times differentiable with $q=2$, i.e., $m(x)$ is a smooth and quadratic function. A Taylor series expansion of $m(x)$ about a target point $P D_{0}$ approximately $m\left(P D_{0}\right)+m^{\prime}\left(P D_{0}\right)\left(P D-P D_{0}\right)+\ldots+m^{(q)}\left(P D_{0}\right) / q !\left(P D-P D_{0}\right)^{q}$. The polynomial terms, $m^{(k)}\left(P D_{0}\right) / k$ ! (or, $\left.\beta_{k}\left(P D_{0}\right)\right)$, are estimated as the coefficients of the weighted least squares problem, which is also the local regression problem:

$$
\underset{\beta\left(P D_{0}\right)}{\operatorname{Min}}\left[\left(R_{M}-P D_{q}\left(P D_{0}\right) \beta\left(P D_{0}\right)\right)^{T} W_{h}\left(P D_{0}\right)\left(R_{M}-P D_{q}\left(P D_{0}\right) \beta\left(P D_{0}\right)\right)\right] .
$$


Where in Equation (6) the rows of $P D_{q}$ are $\left[1\left(P D_{k}-P D_{0}\right) \ldots\left(P D_{k}-P D_{0}\right)^{q}\right], k=1,2, \ldots, n$; and the non-zero diagonal elements of the weighting matrix $W_{h}(),. K\left(P D_{t}-P D_{0}\right) / h^{2}$, are determined with the Epanechnikov kernel, $K$, and the bandwith, $h$, whose values are chosen in local polynomial fitting so that the asymptotic mean square error is optimally minimized.

The Gaussian local correlation matrix will be estimated for the above mentioned ETFs, in both subsample periods, in order to compare each other. Also, we will perform the local Gaussian correlation independence test.

\section{RESULTS}

The estimated Coefficients of Equation (4) are presented in Table 1. We also presented the estimated coefficients of an OLS regression between pricing deviation and the market proxy return for comparison purposes.

Table 1 - Estimated OLS coefficients of Equation (4) on the left side and coefficients of an OLS regression between pricing deviation (PD) and the market proxy return (Ibovespa) on the right side, for comparison purposes. The coefficients were estimated for the 10 largest Brazilian ETFs that were available for the entire sample period. The data was divided in two subsamples: one characterized as the post-subprime crisis and other as the eurozone debt crisis.

\begin{tabular}{|c|c|c|c|c|c|c|c|c|c|}
\hline \multirow[b]{2}{*}{ ETF } & \multirow[b]{2}{*}{ Period } & \multicolumn{4}{|c|}{ Equation (4) } & \multicolumn{4}{|c|}{$P D=\alpha+\beta_{1} R_{M}$} \\
\hline & & Param & Coef & t-stat & $\mathrm{p}$-value & Param & Coef & t-stat & p-value \\
\hline \multirow{4}{*}{ ETF1 } & \multirow{2}{*}{ 2009/2011 } & const & 0.07 & 6.18 & 0.00 & const & 0.00 & -0.26 & 0.79 \\
\hline & & nav1 & 0.97 & 132.70 & 0.00 & ibo & 0.03 & 46.59 & 0.00 \\
\hline & \multirow{2}{*}{$2011 / 2012$} & const & 0.08 & 24.94 & 0.01 & const & 0.00 & -0.14 & 0.89 \\
\hline & & nav1 & 0.93 & 47.05 & 0.00 & ibo & 0.07 & 3.61 & 0.00 \\
\hline \multirow{4}{*}{ ETF2 } & \multirow{2}{*}{$2009 / 2011$} & const & 0.05 & 8.21 & 0.00 & const & 0.00 & -0.07 & 0.95 \\
\hline & & nav2 & 0.99 & 263.60 & 0.00 & ibo & 0.00 & 12.02 & 0.23 \\
\hline & \multirow{2}{*}{$2011 / 2012$} & const & 0.05 & 34.57 & 0.00 & const & 0.00 & -0.06 & 0.95 \\
\hline & & nav2 & 0.99 & 131.23 & 0.00 & ibo & 0.01 & 15.48 & 0.12 \\
\hline \multirow{4}{*}{ ETF3 } & \multirow{2}{*}{$2009 / 2011$} & const & 0.06 & 16.72 & 0.00 & const & 0.00 & -0.04 & 0.97 \\
\hline & & nav3 & 0.99 & 425.60 & 0.00 & ibo & 0.00 & 0.64 & 0.52 \\
\hline & \multirow{2}{*}{$2011 / 2012$} & const & 0.07 & 133.62 & 0.00 & const & 0.00 & -0.02 & 0.98 \\
\hline & & nav3 & 1.00 & 366.59 & 0.00 & ibo & 0.00 & 0.60 & 0.55 \\
\hline
\end{tabular}




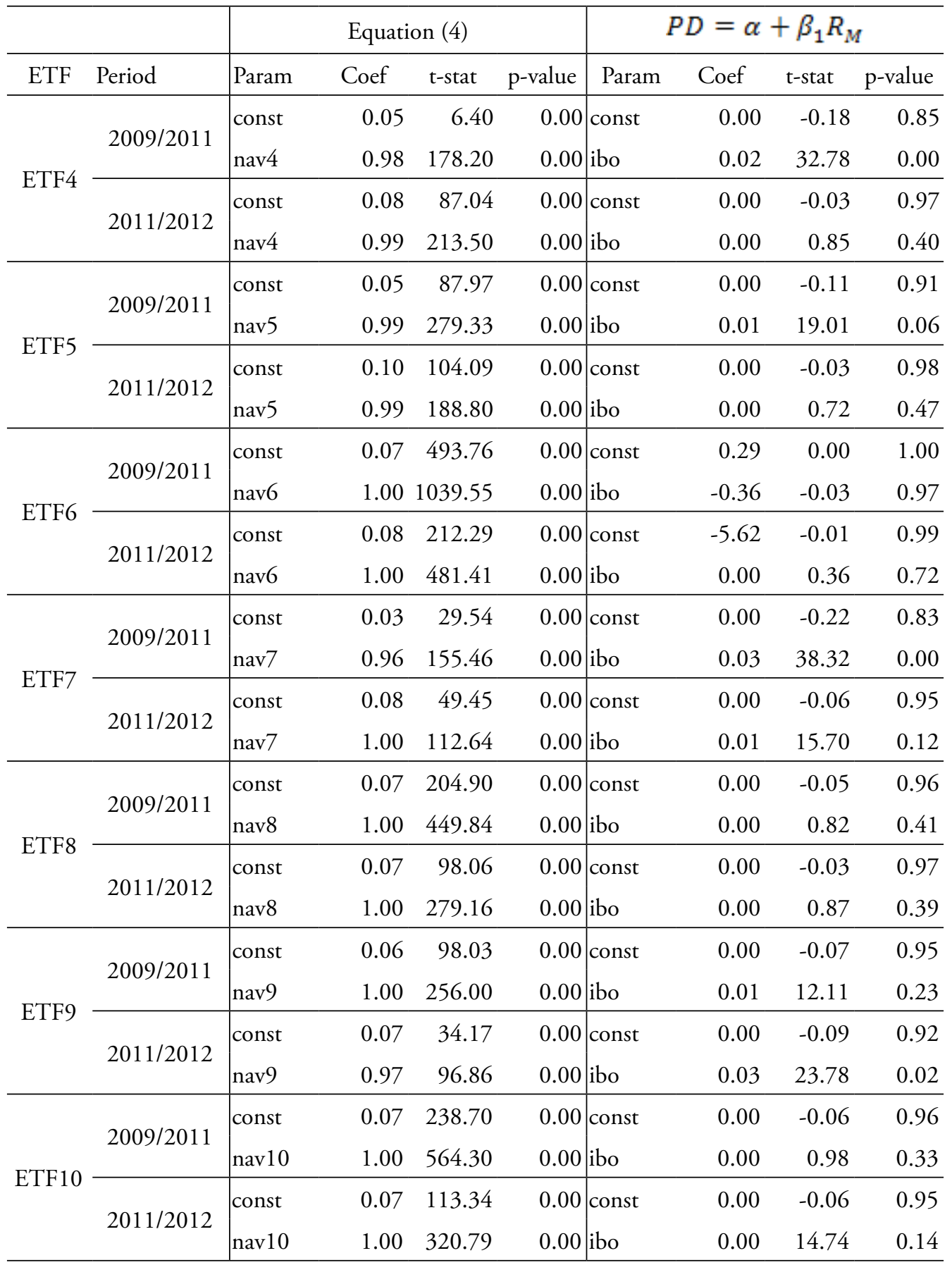

For all the 10 analyzed ETFs, the independent variable of Equation (4) generated significant coefficients in all cases, indicating that the ETF share return is explained by the NAV return. The results were consistent in both subsamples. The second step relies on taking 
the error term of Equation [4], the pricing deviation $(P D)$, and regress against the market proxy return. The right side of the table presents the coefficient of this second estimation. The pricing deviation is only explained by the market proxy return for $\mathrm{ETF}_{1,}$ (both subsamples), $\mathrm{ETF}_{4}$ (first subsample), $\mathrm{ETF}_{7}$ (first subsample) and $\mathrm{ETF}_{9}$ (second subsample). So, if we use OLS regression the pricing deviation is not, in general, explained by market return. But the local correlation approach shows that this relationship may be significant depending on the local we analyze. The OLS regression generates an average coefficient, while the local correlation segregates the analysis between locals. Figure 1 presents the coefficients matrix of Gaussian local correlation between $P D$ and $R_{M}$ during the 2009/03 - 2011/07 period. Blue background was used to negative coefficients and red background to positive. The local Gaussian correlation independence test was also performed, being the significant coefficients circled in yellow.

Figure 1 - Gaussian local correlation of the 2009/03 - 2011/07 period, characterized as the post subprime period. The correlation was estimated as presented in Equation (5). Blue background was used to negative coefficients and red background to positive. The local Gaussian correlation independence test was also performed, being the significant coefficients circled in yellow.

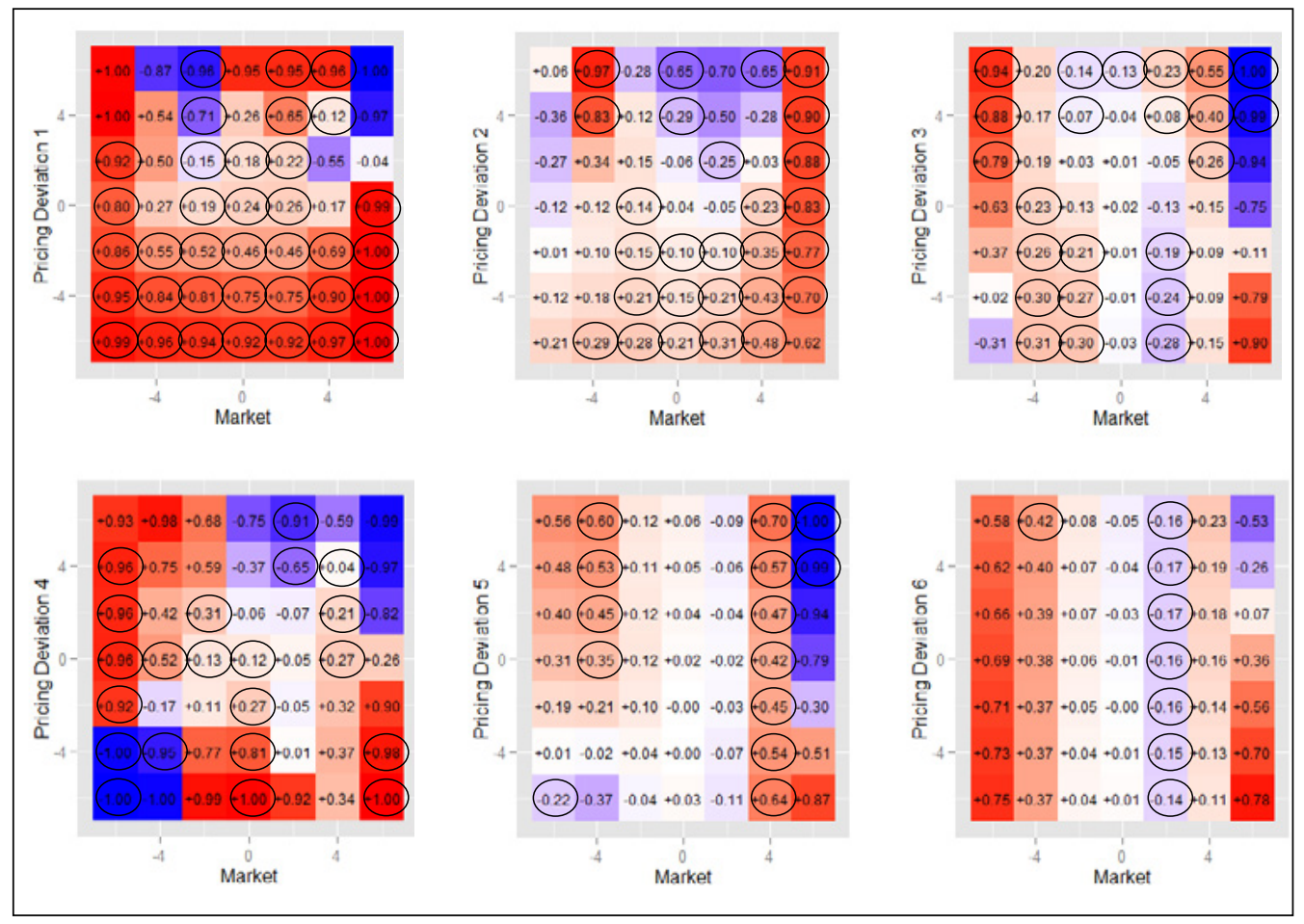




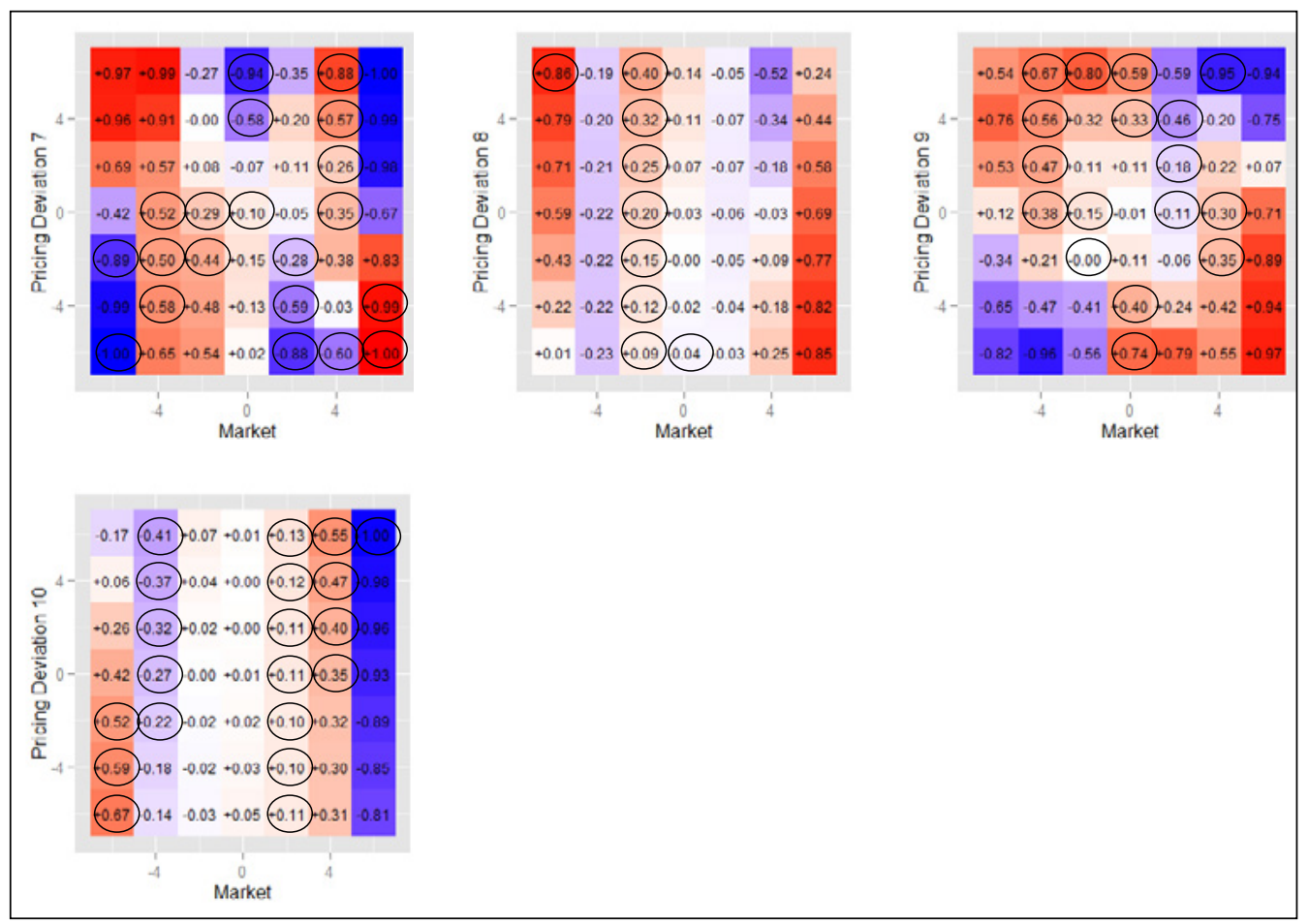

Figure 1 showed some clear standards. $\mathrm{ETF}_{3}, \mathrm{ETF}_{4}, \mathrm{ETF}_{5}, \mathrm{ETF}_{7}, \mathrm{ETF}_{8}$ and $\mathrm{ETF}_{9}$ presented lower correlations on the first and the third quadrant, i.e., where the PD and market return are both high, correlation is smaller. In the same way, where PD and market returns are smaller, correlation is also smaller, almost -1 in several cases. This may indicate that in extreme points market return and PD are heavily linked, but in inversely proportion. The same ETFs presented high correlations in the second and the fourth quadrants, indicating that where market returns are negative (positive) and PD is positive (negative) correlations are higher.

ETF $_{1}$ presented higher correlation where PD is negative; ETF $_{6}$ presented higher correlations where market return is negative; $\mathrm{ETF}_{10}$ presented smaller correlations where market is positive. The lack of correlation near the origin is a strong pattern for all ETFs. All the highest correlations (positive or negative) are located near the extreme points.

Where PD is positive it means that share return is higher than NAV return, what is interesting for an investor who is seeking to beat the market (considering that the ETF underlying portfolio try to mimic the market). In most cases, the first quadrant shows that when PD and the market returns are high the correlation is strongly negative, in most cases. The same happen in the third quadrant: when PD and the market returns are low, PD is strongly positive, presenting inverse behavior.

The second and the fourth quadrant presented very high correlation coefficients, confirming our previous analysis that there is an inverse relation: when market returns are 
high and PD is low, there are high correlations. When market returns are low and PDs are high, the correlation is positively high.

Figure 2 continues the result presentation, showing estimated Gaussian Local Correlation Coefficients for the period after the beginning of euro zone debt crisis.

Figure 2 - Gaussian local correlation of the 2011/07 - 2012/03 period, characterized as the euro zone debt crisis period. The correlation was estimated as presented in Equation (5). Blue background was used to negative coefficients and red background to positive. The local Gaussian correlation independence test was also performed, being the significant coefficients circled in yellow.

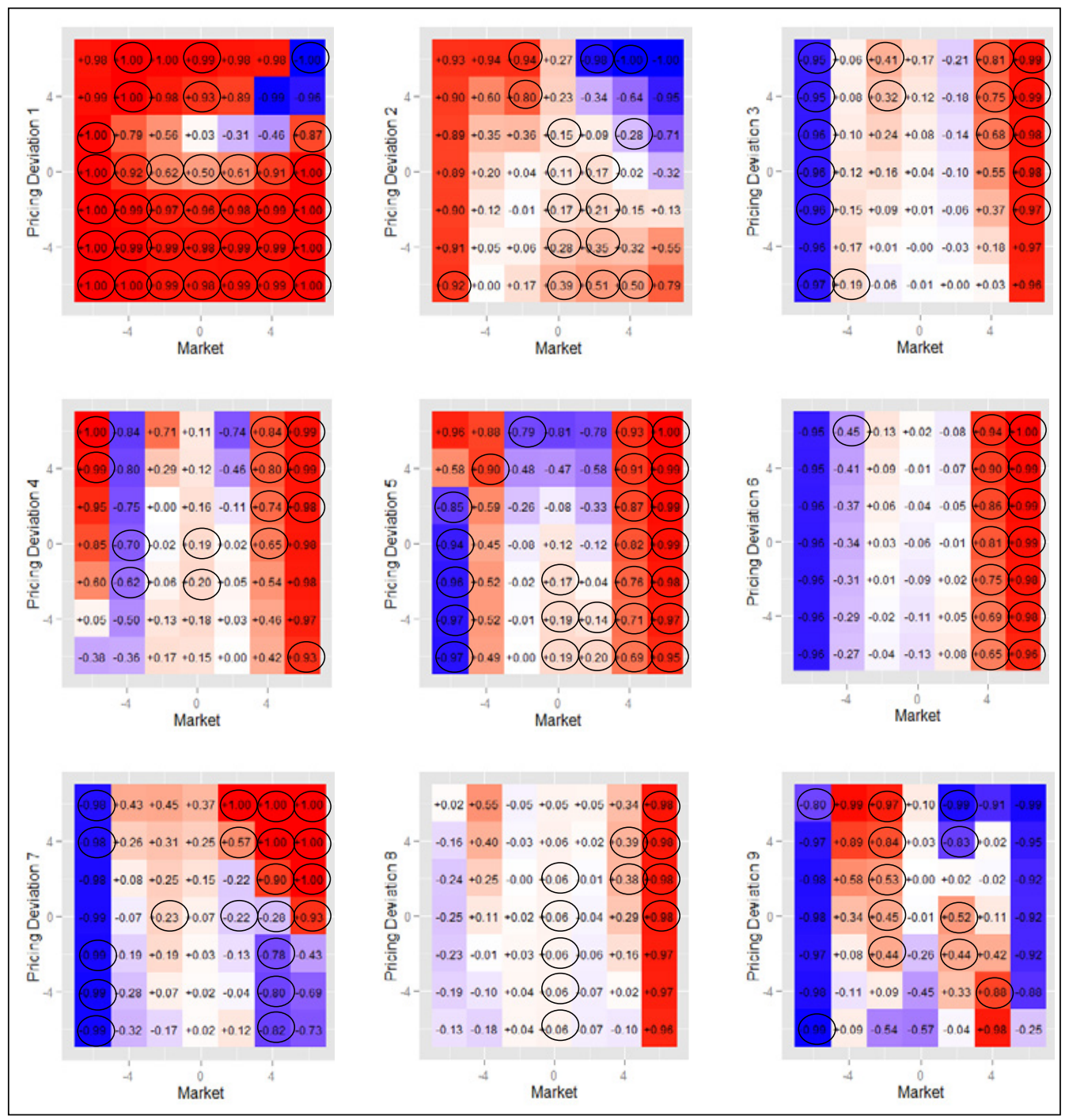




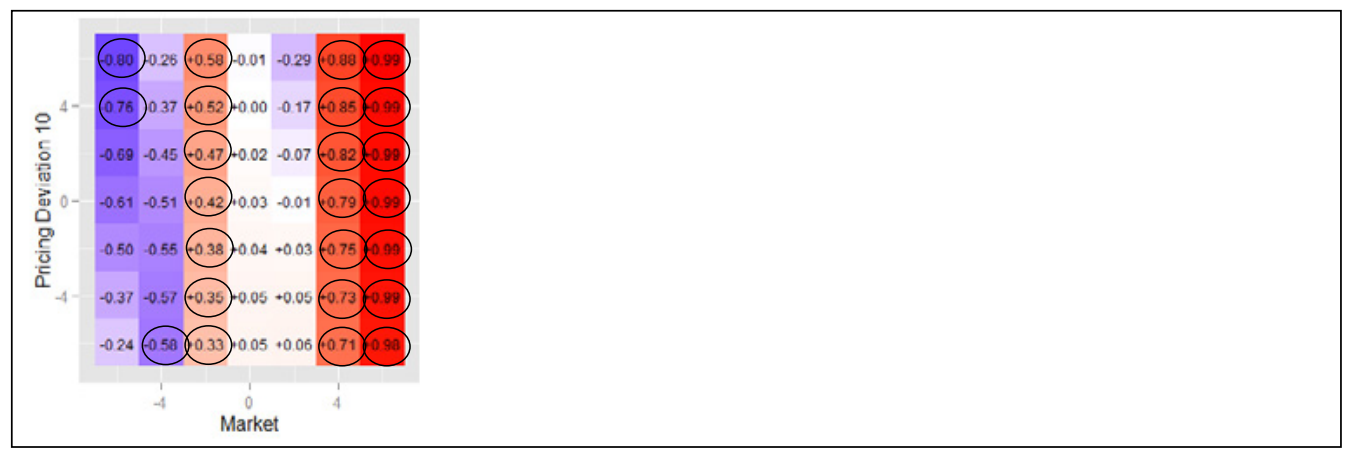

Figure 2 showed that there is a shift on correlation standards after the beginning of euro zone debt crisis, because the correlations seem to became more attached to bear and bull market locals. For $\mathrm{ETF}_{3}, \mathrm{ETF}_{5}, \mathrm{ETF}_{7}, \mathrm{ETF}_{8}, \mathrm{ETF}_{9}$ and $\mathrm{ETF}_{10}$ where the market return is low, correlations are lower. For $\mathrm{ETF}_{3}, \mathrm{ETF}_{4}, \mathrm{ETF}_{5}, \mathrm{ETF}_{6}, \mathrm{ETF}_{8}$ and $\mathrm{ETF}_{10}$, correlations are higher where market is high.

Regarding $\mathrm{ETF}_{1}$, correlation has increased in all places, except on the extreme points of the first quadrant. While in the most cases correlation is high where the market returns are the higher and low where market returns are the lower, for $\mathrm{ETF}_{2}$ and $\mathrm{ETF}_{4}$, however, there is a different standard: correlation is high where market returns are low. ETF $_{2}$ was already different in the previous analysis, showing positive correlation in the first quadrant. $\mathrm{ETF}_{4}$, differently of the others, presented high correlation where the market present low returns. There is another interesting situation concerning $\mathrm{ETF}_{9}$ : correlations are low in both bear and bull market places.

In a general manner, we point that the lowest correlation remained near the origin and that the correlations have increased in general, especially in extreme points. Also, local correlation seemed to become more linked to the market after the beginning of euro zone debt crisis. Independently of the crisis, there are more positive significant correlations than negative significant correlations.

\section{CONCLUSION}

This paper objective is to verify if Brazilian ETFs pricing deviation depends on Market returns and if this relationship present differences depending on two market situations: after subprime crisis and during the eurozone debt crisis. We used two subsamples: the first from March $1^{\text {st }}, 2009$ to July $29^{\text {th }}, 2011$ and the second from July $30^{\text {th }}, 2011$ to March $29^{\text {th }}$, 2012. The first period is characterized as the post subprime crisis and the second, as the euro zone debt crisis. We chose the 10 largest ETFs in Brazil, between those that were available for the entire sample period.

The ETFs pricing deviation was estimated and then we calculated the local correlation between pricing deviation and the market return. We pointed that correlation is higher in extreme points and smaller near the origin. For most funds, the first and the third quadrants 
presented high negative correlations showing that both variables are dependent and that the investor may benefit from this. After the beginning of eurozone debt crisis, correlations arise and a different pattern emerges: correlations are stronger where the market presents higher returns for most ETFs. During the crisis period, ETFs investors are mindful to the market variation. Independently if the ETF is at a premium or at a discount, the correlation with the market will be higher during crisis periods.

Investors seek for ETFs shares that present higher returns than the market, i.e., ETFs with positive PD (premium) and it may be useful to know that during the bear market, pricing deviations present positive correlations with the market, a good result for investors. During bull, pricing deviations present negative correlations with the market, also a good result. This way, Brazilian ETFs may present an interesting opportunity.

\section{REFERENCES}

ACKERT, L.F.; TIAN, Y.S. Arbitrage and valuation in the market for Standard and Poor's depositary receipts. Financial Management, v. 29, pp. 71-87, 2000.

ACKERT, L. F.; TIAN, Y. S. Arbitrage, Liquidity, and the Valuation of Exchange Traded Funds. New York University Salomon Center, Financial Markets, Institutions and Instruments, v. 17, n. 5, 2008.

BERK, J.; STANTON, R. Managerial Ability, Compensation, and the Closed-End Fund Discount. The Journal of Finance, v. 62, n. 2, 2007.

BRADLEY, B.; TAQQU, M. How to estimate spatial contagion between financial markets. Finance Letters, v. 3, p. 64-76, 2005a.

BRADLEY, B.; TAQQU, M. Empirical evidence on spatial contagion between financial markets Finance Letters, v. 3, p. 77-86, 2005 b.

CHARUPAT, N.; MIU, P. Recent Developments in exchange-traded fund literature: pricing efficiency, tracking ability, and effects on underlying securities. Managerial Finance, v. 39, n. 5, pp. 427-443, 2012.

CHARUPAT, N.; MIU, P. The pricing efficiency of leveraged exchange-traded funds: evidence from the U.S. Markets. The Journal of Financial Research, v. 36, n. 2, p. 253277, 2013.

CHORDIA, T.; ROLL, R.; SUBRAHMANYAM, A. Evidence on the speed of convergence to market efficiency. Journal of Financial Economics, v. 76, n. 2, p. 271292, 2005.

CHUNG, D. Y.; HRAZDIL, K. Speed of Convergence to market efficiency in the ETFs market. Managerial Finance, v. 39, n. 5, p. 457-475, 2012. 
CURCIO, R.J.; LIPKA, J.M.; THORNTON, J.H. Jr. Cubes and the individual investor. Financial Services Review, v. 13, p. 123-138, 2004.

DEFUSCO, R. A.; IVANOV, S. I.; KARELS, G. V. The exchange traded funds' pricing deviation: analysis and forecasts. Journal for Economics and Finance, v. 35, p. 181-197, 2011.

ELTON, E.J.; GRUBER, M.J.; COMER, G.; LI, K. Spiders: where are the bugs? Journal of Business, v. 75, n. 3, p. 453-472, 2002.

ENGLE, R.F.; SARKAR, D. Premiums-discounts and exchange traded funds Journal of Derivatives, v. 13, p. 27-45, 2006.

INCI, A. C.; LI, H. C., MCCARTHY, J. Financial Contagion: a local correlation analysis. Research in International Business and Finance, v. 25, p. 11-25, 2011.

JARES, T. E.; LAVIN, A. M. Japan and Hong Kong Exchange-Traded Funds (ETFs): Discounts, Returns and Trading Strategies. Journal of Financial Services, v. 25, n. 1, p. 57-69, 2004.

JENSEN, M. C. The performance of mutual funds in the period of 1945-1964. Journal of Finance, v. 23, n. 2, p. 389-416, 1967.

LINTNER, J. Security Prices, Risk and Maximal Gains from Diversification. Journal of Finance, v. 20, p. 587, 616, 1965.

MARKOWITZ, H. M. Portfolio selection. Journal of Finance, Oxford, v. 7, n. 1, p. 7791, 1952.

MARSHALL, B. R.; NGUYEN, N. H. VISALTANACHOTI, N. ETF arbitrage: Intraday evidence. Journal of Banking and Finance, n. 37, p. 3486-3498, 2013.

MATHUR, A. Partial correlation curves. Working Paper. University of CaliforniaBerkeley, 1998.

MOSSIM, J. Equilibrium in a Capital Asset Market. Econometrica, v. 34, p. 768-783, 1966.

ROMPOTIS, G. G. Actively vs. Passively Managed Exchange Traded Funds. The IEB international Journal of Finance, v. 6, p. 116-135, 2013.

SHARPE, W. F. Mutual Fund Performance The Journal of business, v. 39, n. 1, p.119138, 1966. 